ISSN 0258-7122

Bangladesh J. Agril. Res. 33(3) : 419-425, September 2008

\title{
IN VITRO TUBERIZATION OF POTATO INFLUENCED BY BENZYL ADENINE AND CHLORO CHOLINE CHLORIDE
}

\author{
M. ZAKARIA ${ }^{1}$, M. M. HOSSAIN ${ }^{2}$, M. A. KHALEQUE MIAN ${ }^{3}$, \\ T. HOSSAIN ${ }^{4}$ AND M. Z. UDDIN ${ }^{5}$
}

\begin{abstract}
In an experiment, six levels of benzyl adenine (0.2.5,5.0,7.5,10.0,12.5 and 15.0 $\mathrm{mg} / \mathrm{I}$ ) in combination with three levels of (CCC) chloro choline chloride $(0,125,250$ and $500 \mathrm{mg} / \mathrm{I})$ were evaluated against control treatment $(0)$ in each case to find out their optimum levels for microtuberization in potato variety Diarnant. Microtuberization was the earliest by I 3 days at $10 \mathrm{mg} / \mathrm{I} \mathrm{BA}$. The number and average weight of microtuber per flask vas increased with increasing rate of BA and reached maximum of 12.9 and $252.1 \mathrm{mg}$ respectively at $10 \mathrm{mg} / \mathrm{I}$ BA and decreased onwards with further increase of BA concentration. The increase rate of CCC increased the number of microtuber but decreased average weight. The maximum number and average weight of microtuber were recorded at $500 \mathrm{mg} / \mathrm{I} \mathrm{CCC}$ and in absence of CCC respectively.
\end{abstract}

Key Words: BA, CCC, potato, microtuber.

\section{Introduction}

Microtubers have become an important mode of rapid multiplication for prebasic stock in seed tuber multiplication as well as gerrnplasrn exchange. The number and size of microtubers produced in vitro depend on many factors, such as optimum concentration of sugar, growth regulators and anti-gibberellin compounds in the culture medium (Tovar et al., 1985; Dodds et al., 1988). Among the substances used to induce microtubers, cournarin, CCC and cytokinins have received adequate attention (Wang and Hu, 1985; Chandra ci a!.. 1988). Cytokinins are believed to have strong promotive effects on tuberization, and to constitute major part of the tuberization stimulus, either alone or in combination with other substances (Palmer and Smith, 1969; Pelacho and Mingo-Castel, 1991). Growth retardant stimulates tuberization of plants under unfavourable environmental conditions (Menzel. 1980) and CCC (Chioro choline chloride) is widely used in tissue culture media to promote microtuher formation (Tovar et al., 1985 and Rosell et al., 1987). It induces microtuber formation by a wide range of Solanum genotypes of diverse genetic backgrounds (Estrada et al., 1986). Although CCC stimulates tuber initiation by recalcitrant genotypes, it can

\footnotetext{
${ }^{1}$ Asstt. Professor, Deptt. of Horticulture, ${ }^{2}$ Professor, Deptt. of Horticulture, ${ }^{3}$ Professor, Deptt. of Genetics and Plant Breeding, ${ }^{4}$ Professor, Deptt. of Crop Botany, BSMRAU, Gazipur, ${ }^{5}$ Senior Scientific Officer, HRC, BARI, Gazipur-1701, Bangladesh.
} 
inhibit microtuher growth in Solanum tuberosum cultivars that form tubers readily in its absence. Vecchio et al. (1994) reported that in vitro tuberization is linked with the genotype and the culture substratum. According to them, the potato variety Desiree tuberized readily than other varieties with a low CCC concentration. Very little information is available about the influence of BA and CCC in microtuberization on the recommended variety Diamant. Therefore, the present investigation was undertaken to determine the optimum level ol BA and CCC for getting higher proportion of large size microtubers of Diamant.

\section{Materials and Method}

In vitro ready stocks of plantlets of potato variety Diamant were used and the number of plantlets was increased by subculturing via nodal cutting at 3 weeks interval. The multiplication medium contained mineral salts and vitamins (Murashige and Skoog. 962) plus $0.1 \mathrm{mg} / \mathrm{I} \mathrm{GA} 3,0.01 \mathrm{mg} / \mathrm{I}$ NAA, $4 \mathrm{mg} / \mathrm{I}$ calcium pantathonate and 30g/l sucrose. The medium was solidified with $8 \mathrm{~g} / \mathrm{l}$ agar. Temperature in the growth chamber was $23 \pm 1^{\circ} \mathrm{C}$ with 16 hours photoperiod and light was supplied by fluorescent tubes at an intensity of 3000 lux.

Eight stem segments (each with 3 nodes) of subcultured in vitro plantlets were cultured in $250 \mathrm{ml}$ Erlenmeyer flasks containing $40 \mathrm{ml}$ microtuber induction medium, which was based on MS medium (Murashige and Skoog. 1962) supplemented with $80 \mathrm{~g} / \mathrm{l}$ sucrose. Six levels of Benzyl adenine (BA) and three levels Chloro choline chloride (CCC) having control treatment (0) in each case were added in the culture medium, which in combination made 28 treatment combinations. The experiment was laid out in a Completely Randomized Design (CRD) with four replications. The number of flask per replication was 72 . The induced microtubers were harvested aseptically after 70 days of incubation period. The collected data were analyzed with the help of computer using MSTAT-5 program and the mean separation was done by Duncan's new multiple range test.

\section{Results and Discussion}

Effect of Benzyl Adenine: Microtuberization was the earliest (13.3 days) at 10 mg/I BA (Table 1). Either higher or lower concentration of this level greatly delayed tuherization. Plants grown in the medium without BA took the longest time for tuberization (20.1 days). The number of microtuber per flask increased with increasing rate of BA upto $10 \mathrm{mg} / \mathrm{I}$, and then gradually decreased with further increase of BA concentration. The results are similar to the findings of Wang and $\mathrm{Hu}$ (1982) who reported that at a higher concentrations of BA above $10 \mathrm{mg} / \mathrm{I}$ in the medium decreased the number of microtubers. The concentration 
of BA at $10 \mathrm{mg} / \mathrm{I}$ produced the highest weight of microtuber $(252.1 \mathrm{mg})$ as compared to other concentrations. This agreed well with the results of similar works by other workers (Wang and Hu, 1982; Teixeira and Pinto, 1991). The highest percentage of $>300 \mathrm{mg}$ size microtuher was produced with $10 \mathrm{mg} / \mathrm{I}$ BA (28.7), while no microtuber of $>300 \mathrm{mg}$ size was found vith 2.5 and $5.0 \mathrm{mg} / \mathrm{I} \mathrm{BA}$ (Table 1).

Table 1. Effect of BA on induction and development of potato microtuber.

\begin{tabular}{|c|c|c|c|c|c|c|}
\hline \multirow[b]{2}{*}{ BA (mg/I) } & \multirow{2}{*}{$\begin{array}{c}\text { Days to } \\
\text { tuber } \\
\text { initiation }\end{array}$} & \multirow{2}{*}{$\begin{array}{c}\text { No. of } \\
\text { microtubers/ } \\
\text { flask }\end{array}$} & \multirow{2}{*}{$\begin{array}{l}\text { Av. wt of } \\
\text { microtuber } \\
(\mathrm{mg})\end{array}$} & \multicolumn{3}{|c|}{ Grade of microtuber by number (\%) } \\
\hline & & & & $<150 \mathrm{gm}$ & $\begin{array}{c}150- \\
300 \mathrm{mg}\end{array}$ & $>300 \mathrm{mg}$ \\
\hline 0 & $20.1 \mathrm{~d}$ & $6.5 \mathrm{e}$ & $83,6 \mathrm{f}$ & 100 & 0 & 0 \\
\hline 2.5 & $17.6 \mathrm{c}$ & 7.3 de & $117.6 \mathrm{e}$ & 91.3 & 8.7 & 0 \\
\hline 5.0 & $16.2 b$ & $7.8 \mathrm{~d}$ & 160.Od & 48.4 & 51.6 & 0 \\
\hline 7.5 & $15.4 \mathrm{~b}$ & $9.3 \mathrm{c}$ & $185.8 \mathrm{c}$ & 38.6 & 53.2 & 8.2 \\
\hline 10.0 & 13.3 a & 12.9 a & $252.1 \mathrm{a}$ & 27.0 & 44.3 & 28.7 \\
\hline 12.5 & $16.0 \mathrm{~b}$ & $10.7 \mathrm{~b}$ & $199.6 \mathrm{~b}$ & 40.6 & 50.0 & 9.4 \\
\hline 15.0 & $18.4 \mathrm{c}$ & $9.2 \mathrm{c}$ & $168.1 \mathrm{~d}$ & 43.1 & 54.0 & 2.9 \\
\hline $\begin{array}{l}\text { Level of } \\
\text { significance }\end{array}$ & $* *$ & $* *$ & $* *$ & & & \\
\hline
\end{tabular}

Commonly, cytokinins are included in the media for in vitro tuberization of potatoes (Wang and $\mathrm{Hu}, 1982$ ). Cytokinins promote in vitro tuberization of potato by altering GA balance in non-induced stems (Lentini and Earle, 1991), inhibiting root formation and transferring the upright leafy shoots into horizontal stolons (Shibli et al., 2001). At 2\% sucrose, cytokinin fails to exert stimulating effect of tuherization at any concentration (Koda and Okazawa, 1983). They further noted that sucrose concentration at above $4 \%$, cytokinins exhibited a promoting effect on tuberization. Requirement of high concentration of sucrose by cytokinins for in vitro tuberization was also reported by Palmer and Smith (1969) and Wang and Hu (1982). For several reasons, cytokinin has often been considered to be an important factor for tuberization process. Firstly, cytokinin is known to stimulate cell division (Skoog and Miller, 1957); secondly, there are indications that it inhibits cell elongation (Vanderhoef and Key, 1968), and promote cell expansion (Scott and Liverman. 1956). These phenomena are required for tuber formation and development. Several workers have, therefore, suggested that the unknown tuberization stimulus could be a cytokinin like substance (Madec, 1963; Courduroux, 1966). Although cytokinin is not directly responsible for tuberization as reported by many workers, without doubt, it plays a key role in cell division and thus creating sink activity of the developing tuber. 
Effect of chioro choline chloride (CCC): The time required for tuber initiation was reduced with increasing concentration of CCC (Table 2). Tuberization was the most early with CCC concentration at $500 \mathrm{mg} / \mathrm{I}$ (15.9 days), while it was the most delayed in absence of CCC (17.8 days). These findings were in agreement with Hossain and Sultana (1998) who reported most early tuberization with 500 $\mathrm{mg} / \mathrm{I}$ CCC. The number of microtubers was increased with increasing concentration of CCC. The maximum number of microtubers was produced with CCC concentration at $500 \mathrm{mg} / \mathrm{I}$ (9.9), while the minimum was 8.1 in absence of CCC. The results were also similar with Hossain and Sultana (1998) who found maximum number of microtubers per plant with $500 \mathrm{mg} / \mathrm{I}$ CCC. Weight of microtuber was decreased with increasing rate of CCC concentration. The highest tuber weight was recorded in absence of CCC (190.1 mg), while the minimum at $500 \mathrm{mg} / \mathrm{I}$ CCC (145.7 mg). These findings disagreed with those of Hossain and Sultana (1998) in respect of weight but agreed with Harvey et al. (1991), Leclerc et al. (1994), and Lian-Yong et al. (1996). The highest percentage (13.7) of >300 $\mathrm{mg}$ size microtuber was produced in absence of CCC which was closely followed by low concentration (125 mg/I) of CCC (8.0) (Table 2).

Table 2. Effect of CCC on induction and development of potato microtuber

\begin{tabular}{|c|c|c|c|c|c|c|}
\hline \multirow[b]{2}{*}{ CCC (mg/I) } & \multirow{2}{*}{$\begin{array}{l}\text { Days to } \\
\text { tuber } \\
\text { initiation }\end{array}$} & \multirow{2}{*}{$\begin{array}{c}\text { No. of } \\
\text { microtubers/ } \\
\text { flask }\end{array}$} & \multirow{2}{*}{$\begin{array}{l}\text { Av. wt of } \\
\text { microtuber } \\
(\mathrm{mg})\end{array}$} & \multicolumn{3}{|c|}{ Grade of microtuber by number (\%) } \\
\hline & & & & $<150 \mathrm{gm}$ & $\begin{array}{c}150- \\
300 \mathrm{mg}\end{array}$ & $>300 \mathrm{mg}$ \\
\hline 0 & 17.8 & $8.1 \mathrm{~b}$ & $190.1 \mathrm{a}$ & 48.6 & 37.7 & 13.7 \\
\hline 125 & 16.9ab & 8.9ab & $173.3 \mathrm{~b}$ & 53.6 & 38.4 & 8.0 \\
\hline 250 & 16.3 & $9.5 \mathrm{a}$ & $157.5 \mathrm{c}$ & 59.0 & 37.6 & 3.4 \\
\hline 500 & $15.9 a$ & 9.9a & $145.7 d$ & 61.0 & 35.9 & 3.1 \\
\hline $\begin{array}{l}\text { Level of } \\
\text { significance }\end{array}$ & $* *$ & $* *$ & $* *$ & & & \\
\hline
\end{tabular}

Interaction effect of BA and CCC: Tuberization was the earliest (12.7 days) with $10 \mathrm{mg} / \mathrm{l} \mathrm{BA}$ in combination with $500 \mathrm{mg} / \mathrm{I}$ CCC (Table 3). This might be due to the combined beneficial effect of BA (Teixeira and Pinto, 1991) and CCC (Hossain and Sultana, 1998). The minimum number of microtubers per flask was 5.0 in absence of both BA and CCC, while it was highest with $10 \mathrm{mg} / \mathrm{I} \mathrm{BA}$ in combination with $500 \mathrm{mg} / \mathrm{I}$ CCC (13.7). This might be due to the positive effect of both BA (Wang and Hu, 1982) and CCC (Lian-Yong et al., 1996) in the medium. The highest average weight of microtuber was recorded with $10 \mathrm{mg} / \mathrm{I}$ BA in absence of CCC (292.3 mg), which was closely followed by the same concentration of BA (10 mg/I BA) in combination with low concentration (125 $\mathrm{mg} / \mathrm{I})$ of CCC. The maximum weight of microtuber with $10 \mathrm{mg} / \mathrm{I}$ BA without CCC might be due to the presence of beneficial effect of BA (Teixeira and Pinto, 
1991) and absence of harmful effect of CCC (Leclerc et al., 1994 and Lian-Yong et al., 1996).

Table 3. Interaction effect of BA and CCC on induction and development of potato microtuber.

\begin{tabular}{|c|c|c|c|c|c|c|c|}
\hline \multirow{2}{*}{\multicolumn{2}{|c|}{$\begin{array}{c}\text { Treatment } \\
\text { Combination BA } \\
(\mathrm{mg} / \mathrm{I}) \times \mathrm{CCC} \\
(\mathrm{mg} / \mathrm{I}) \\
\end{array}$}} & \multirow{2}{*}{$\begin{array}{l}\text { Days to } \\
\text { tuber } \\
\text { initiation }\end{array}$} & \multirow{2}{*}{$\begin{array}{c}\text { No. of } \\
\text { microtubers/ } \\
\text { flask }\end{array}$} & \multirow{2}{*}{$\begin{array}{l}\text { Av. wt of } \\
\text { microtuber } \\
\text { (mg) }\end{array}$} & \multicolumn{3}{|c|}{$\begin{array}{c}\text { Grade of microtuber by number } \\
(\%)\end{array}$} \\
\hline & & & & & $<150 \mathrm{mg}$ & $150-300 \mathrm{mg}$ & $>300 \mathrm{mg}$ \\
\hline \multirow{4}{*}{0} & 0 & $22.3 \mathrm{k}$ & \multirow{4}{*}{$\begin{array}{l}5.0 \mathrm{i} \\
6.3 \mathrm{ij} \\
7.0 \mathrm{~g}-\mathrm{j}\end{array}$} & 89.2 o & 100.0 & 0 & 0 \\
\hline & 125 & $20.0 \mathrm{j}$ & & 85.3 o & 100.0 & 0 & 0 \\
\hline & $\times \quad 250$ & $19.3 \mathrm{ij}$ & & 83.8 o & 100.0 & 0 & 0 \\
\hline & 500 & 18.7 ghi & & 76.2 o & 100.0 & 0 & 0 \\
\hline \multirow{4}{*}{2.5} & 0 & 19.0 hij & $6.3 \mathrm{ij}$ & $126.4 \mathrm{mn}$ & 85.1 & 14.9 & 0 \\
\hline & 125 & $17.7 \mathrm{f}-\mathrm{j}$ & $7.0 \mathrm{~g}-\mathrm{i}$ & $119.3 \mathrm{n}$ & 88.3 & 11.7 & 0 \\
\hline & $\begin{array}{l}x \quad 250 \\
x\end{array}$ & $17.0 \mathrm{e}-\mathrm{i}$ & $7.7 \mathrm{f}-\mathrm{i}$ & $115.6 \mathrm{n}$ & 91.9 & 8.1 & 0 \\
\hline & 500 & 16.7 e-i & $8.0 \mathrm{e}-\mathrm{i}$ & $109.1 \mathrm{n}$ & 100.0 & 0 & 0 \\
\hline \multirow{4}{*}{5.0} & 0 & 17.0 e-i & $6.7 \mathrm{~h}-\mathrm{j}$ & 175.2 hi & 43.6 & 56.4 & 0 \\
\hline & 125 & $16.3 \mathrm{~d}-\mathrm{g}$ & $7.3 \mathrm{~g}-\mathrm{j}$ & 162.4 i-j & 47.4 & 52.6 & 0 \\
\hline & $\begin{array}{l}\times \quad 250 \\
\times\end{array}$ & $16.3 \mathrm{~d}-\mathrm{g}$ & $8.3 \mathrm{e}-\mathrm{i}$ & $153.1 \mathrm{jkl}$ & 50.1 & 49.9 & 0 \\
\hline & 500 & 15.0 b-e & $9.0 \mathrm{e}-\mathrm{i}$ & $149.32 \mathrm{kl}$ & 52.3 & 47.7 & 0 \\
\hline \multirow{4}{*}{7.5} & 0 & $16.3 \mathrm{~d}-\mathrm{g}$ & 8.0 e-i & 210.1 efg & 30.2 & 49.1 & 20.7 \\
\hline & $\begin{array}{l}125 \\
\times \quad 12\end{array}$ & $15.7 \mathrm{c}-\mathrm{f}$ & $9.3 \mathrm{~d}-\mathrm{i}$ & $191.3 \mathrm{gh}$ & 34.3 & 53.4 & 12.3 \\
\hline & $\begin{array}{l}X \quad 250 \\
X\end{array}$ & 15.0 d-e & $9.7 \mathrm{~d}-\mathrm{h}$ & $176.4 \mathrm{hg}$ & 44.8 & 55.2 & 0 \\
\hline & 500 & 14.7 a-e & 10.0 c-g & 176.4 hi & 45.1 & 54.9 & 0 \\
\hline \multirow{4}{*}{$10.0>$} & 0 & $14.0 \mathrm{a}-\mathrm{d}$ & 12.0 a-b & 292.3 a & 23.1 & 36.7 & 40.2 \\
\hline & 125 & $13.7 \mathrm{abc}$ & $12.7 \mathrm{abc}$ & 261.4 b & 26.7 & 44.2 & 29.1 \\
\hline & 250 & $13.0 \mathrm{ab}$ & $13.3 \mathrm{ab}$ & 240.6 c & 28.7 & 47.4 & 23.9 \\
\hline & 500 & $12.7 \mathrm{a}$ & $13.7 \mathrm{a}$ & $214.1 \mathrm{ef}$ & 29.3 & 48.9 & 21.8 \\
\hline \multirow{4}{*}{$12.5 \times$} & 0 & 16.6 e-h & 10.0 c-g & $238.2 \mathrm{~cd}$ & 28.1 & 48.4 & 23.5 \\
\hline & 125 & 16.0 c-f & $10.7 \mathrm{~b}-\mathrm{f}$ & $220.3 \mathrm{de}$ & 36.4 & 49.5 & 15.1 \\
\hline & 250 & 15.7 c-f & 10.0 a-e & 175.7 hi & 48.7 & 51.3 & 0 \\
\hline & 500 & 15.7 c-f & 11.0 a-e & $164.1 \mathrm{ijk}$ & 49.1 & 50.9 & 0 \\
\hline \multirow{4}{*}{$15.0 \times$} & 0 & 19.0 hji & $8.7 \mathrm{e}-\mathrm{i}$ & $199.5 \mathrm{fg}$ & 30.1 & 58.2 & 11.7 \\
\hline & 125 & 18.7 g-j & 9.0 e-i & $173.2 \mathrm{hij}$ & 42.3 & 57.3 & 0 \\
\hline & 250 & $18.0 \mathrm{f}-\mathrm{j}$ & $9.3 \mathrm{~d}-\mathrm{i}$ & $157.4 \mathrm{i}-\mathrm{j}$ & 48.7 & 51.3 & 0 \\
\hline & 500 & $18.0 \mathrm{f}-\mathrm{j}$ & $9.7 \mathrm{~d}-\mathrm{h}$ & $142.3 \mathrm{~lm}$ & 51.3 & 48.7 & 0 \\
\hline \multicolumn{2}{|c|}{$\begin{array}{l}\text { Level of } \\
\text { significance }\end{array}$} & * & $*$ & $* *$ & & & \\
\hline
\end{tabular}

Chloro choline chloride (CCC) at all concentrations produced cent percent small microtuber ( $<150 \mathrm{mg}$ ) in absence of BA and it did not produce any microtuber of $>300 \mathrm{mg}$ size in presence of BA concentration upto $5.0 \mathrm{mg} / \mathrm{I}$. Benzyl Adenine (BA) at $10.0 \mathrm{mg} / \mathrm{I}$ produced the highest percentage $(40.2 \%)$ of $>300 \mathrm{mg}$ size microtuber in absence of CCC, which was closely followed by same concentration of BA in presence of low concentration (125 mg/I) of CCC. 


\section{References}

Chandra, R., J. H. Dodds and P. Tovar. 1988. In vitro tuberization in potato. Newslet. Intl. Assoc. Plant Tissue Cult. 55: 10-12.

Courduroux, J. C. 1966. Etude du mecamisme physiologique de Ia tuberization chez Ic topinambour. These de Ia Faculte des scidi I Vniv de chermont Ferrind. pp. 54-56.

Dodds, J. H., P. Tovar, R. Chandra, D. Estrella and R. Cabello. 1988. Improved methods for in vitro tuber induction and use of in vitro tubers in seed programs. In: Proc. Symp. on Improved Potato Planting Meterial, kunming, China, June 21-24. 1988. Asian Potato Assoc. pp. 157-158.

Estrada, R.. P. Tovar and J. H. Dodds. 1986. Induction of in vitro tubers in a broad range of potato genotypes. Plant Cell Tiss. Org. Cult. 7: 3-10.

Harvey. B. M. R., S. H. Crothers, N. E. Evans and C. Selby. 1991. The use of growth retardants to improve microtuber formation by potato. Plant Cell Tiss. Org. Cult. 27: 5 9-64.

Hossain M. J. and N. Sultana. 1998. Effect of benzylarnino purine (BAP) and chloro choline choride (CCC) on in vitro tuberisation of potato. Bangladesh J. Agril. Res. 23(4): 685- 690.

Koda. Y. and Y. Okazawa. 1983. Influences of environmental, hormonal and nutritional factors on potato tuberization in vitro. Japan. J. Crop Sc. 52: 582-591.

Leclerc, Y., D. J. Donnely and J. E. A. Seabrook. 1994. Microtuberization of layered shoots and nodal cuttings of potato: the influence of growth regulators and incubation periods. Plant Cell Tiss. Org. cult. 37(2): 113-120.

Lentini, Z and E. D. Earle. 1991. In vitro tuberization of potato clones from different maturity groups. Plant Cell Rep. 9: 691- 695.

Lian-Yong, D. H., X. Xin, Y. Hongfu, J. Liping, L. Huan and Z. Ying. 1996. Changes of several endogenous phytohormones during in vitro tuberization in potato. In : Asian Sweetpotato and Potato Research and Development (Rasco. E. T. and F. B. Aromin eds.). Manila. July 1995-June 1996. Vol. 1: Potato. p. 30-37.

Madec, P. 1963. Tuber forming substances in Potato. In: Growth of the Potato (lins. J. I). and F. L. Milthorpe. Eds). Butterworth. London. pp. 121-131.

Menzel, C. M. 1980. Tuberization in potato at high temperature: Responses to gibberellin and growth inhibitors. Ann. Bot. 46: 259-265.

Murashige, T. and F. Skoog. 1962. A revised medium for rapid growth and bioassays with tobacco tissue cultures. Physiol. Plantarum 15: 473-497.

Palmer, C. E. and 0. E. Smith. 1969. Cytokinins and tuber initiation in the potato Solanurn tuberosum L. Nature 221: 279-2 80.

Pelacho, A. M. and A. M. Mingo-Castel. 1991. Jasmonic acid induces tuberization of potato stolons cultured in vitro. Plant Physiol. 97: 1253-1255.

Rosell, G.. F. G. Bertoldi and R. Tizio. 1987. In vitro mass tuberization as a contribution to potato micropropagation. Potato Res. 30: 111-116. 
Scott. P. A. and J. L. Liverman. 1956. Promotion of leaf expansion by kinetin and benzyl amino purine. Plant Physiol. 31: 321-322.

Shibli, R. A., A. M. Abu-Ein and M. M. Ajlouni. 2001. In vitro and/n vivo multiplication of virus free 'Spunta' potato. Pak. J. Bot. 33: 35-41.

Skoog, F. and C. 0. Miller. 1957. Chemical regulation of growth and organ formation in plant tissues cultured in vitro. In: Symp. Soc. Expt I. Bot. 11: II 8-130.

Teixeira, D. M. C. and J. E. B. P. Pinto. 1991. Minituberization of potatoes at different levels of N, saccharose and BAP. Revista Brasileria de Fisiologia Vegetal. 3(3): 77-83.

Tovar, P., R. Estrada, L. Schilde-Rentschler and J. H. Dodds. 1985. Induction of in vitro potato tubers. CIP Circular 13: 1-4.

Vanderhoef, L. and J. L. Key. 1968. Inhibition by kinetin of cell elongation and RNA synthesis in excised soybean hypocotyls. Plant Cell Physiol. 9: 343-351.

Vecchio, V.. S. G. Ferraro, M. T. Pagano and L. Andrenelli. 1994. Effect of saccharose and CCC on in vitro production of microtubers of potato cultivars. Sementi-Elette (Italy). 40(5): 63-68.

Wang, P. J. and C. Y. Hu. 1982. In vitro mass tuberisation and virus-free seed potato production in Taiwan. Am. Potato J. 59: 33-37.

Wang, P. J. and C. Y. Hu. 1985. Potato tissue culture and its application. In: Potato Physiology. P. H. Li ed., Academic Press, London, pp. 503-577. 